\title{
Stephen Leacock and His Books
}

\section{by The Editors}

Stephen Leacock published during his lifetime a multitude of magazine stories and books. The following pages reproduce the dust jackets or covers of some of these books. Their design and style both evoke another era and present Leacock as he appeared to contemporary readers. All the illustrations are taken from copies in the Leacock Collection in the Department of Rare Books and Special Collections.

De son vivant, Stephen Leacock a publié une foule de livres et de récits pour magazines. Les jaquettes et couvertures de certains de ces ouvrages sont reproduites aux pages suivantes. Leur style et leur conception évoquent une autre époque et présentent Leacock tel qu'il apparaissait à ses lecteurs. Toutes les illustrations proviennent de la collection Leacock du département des livres rares et collections spéciales. 
Stephen Leacock and His Books

\section{BEHIND THE BEYOND BY STEPHEN LEACOCK}

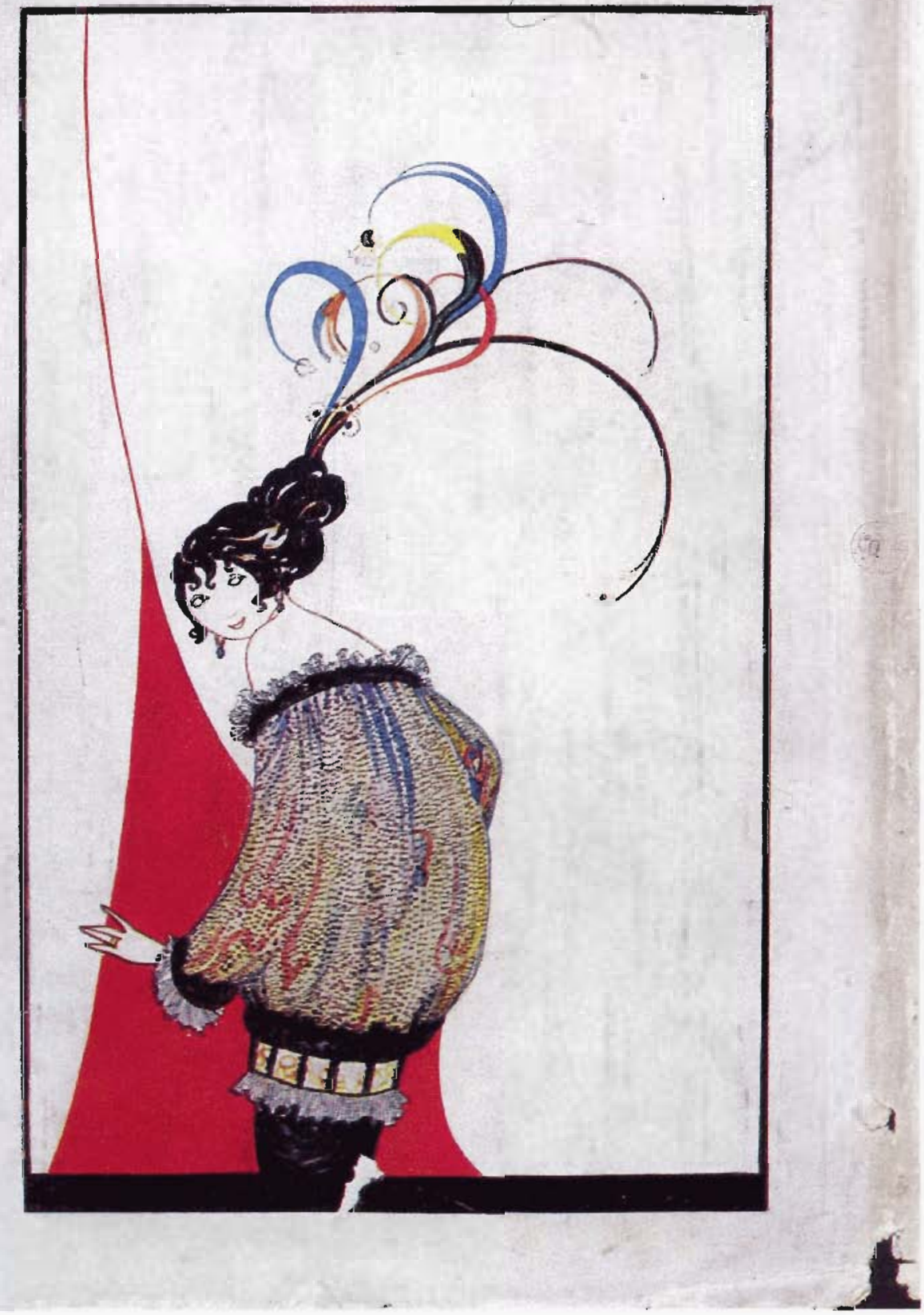

London: John Lane, The Bodley Head 1914 


\section{T부르 \\ MARIONETTES CALENDAR I9I6.}

Nor 14.1938 SFenten Leacock

Rbymes by Stephen Leacock.

Drawings by 76. t6. Fish.

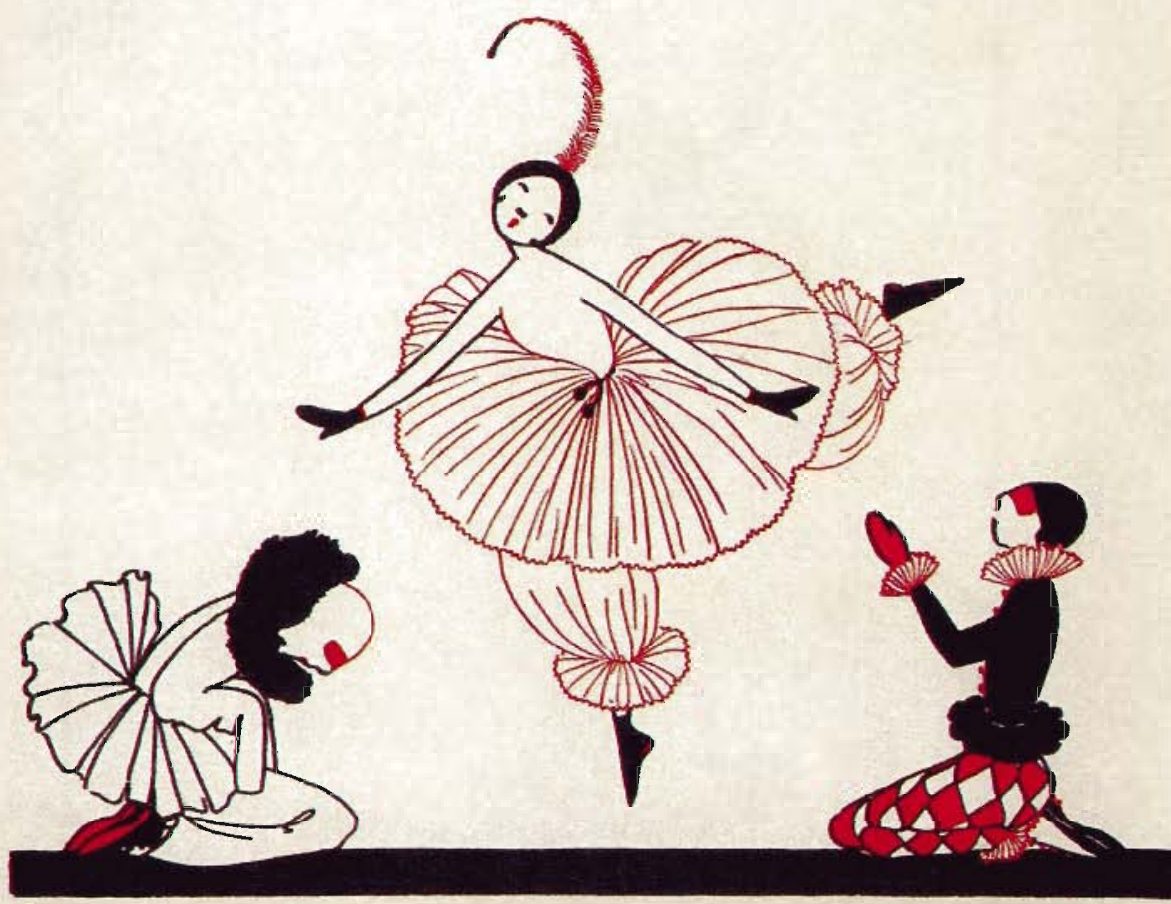

London: John Lane, The Bodley Head

[1916] 


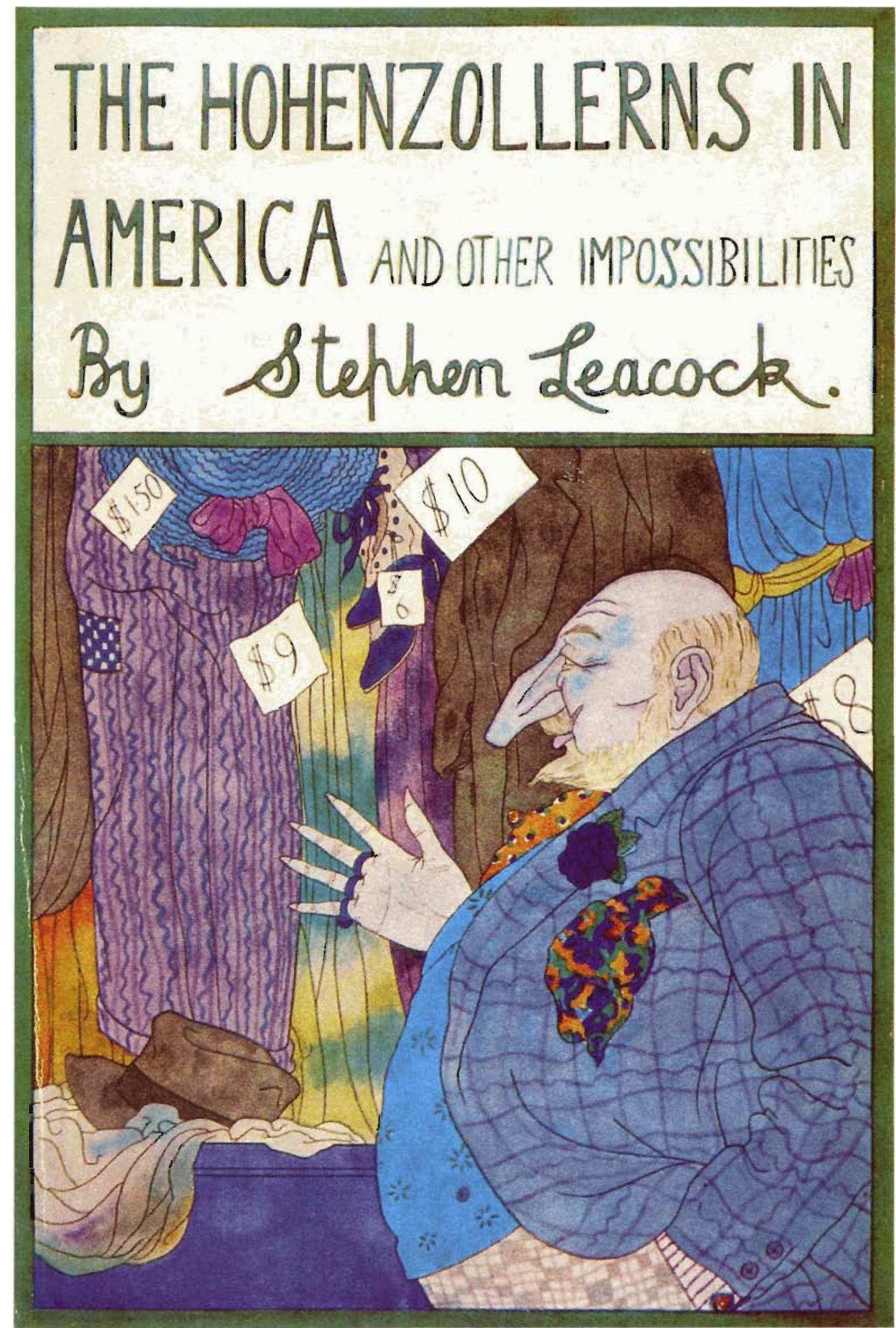

London: John Lane, The Bodley Head

1919 


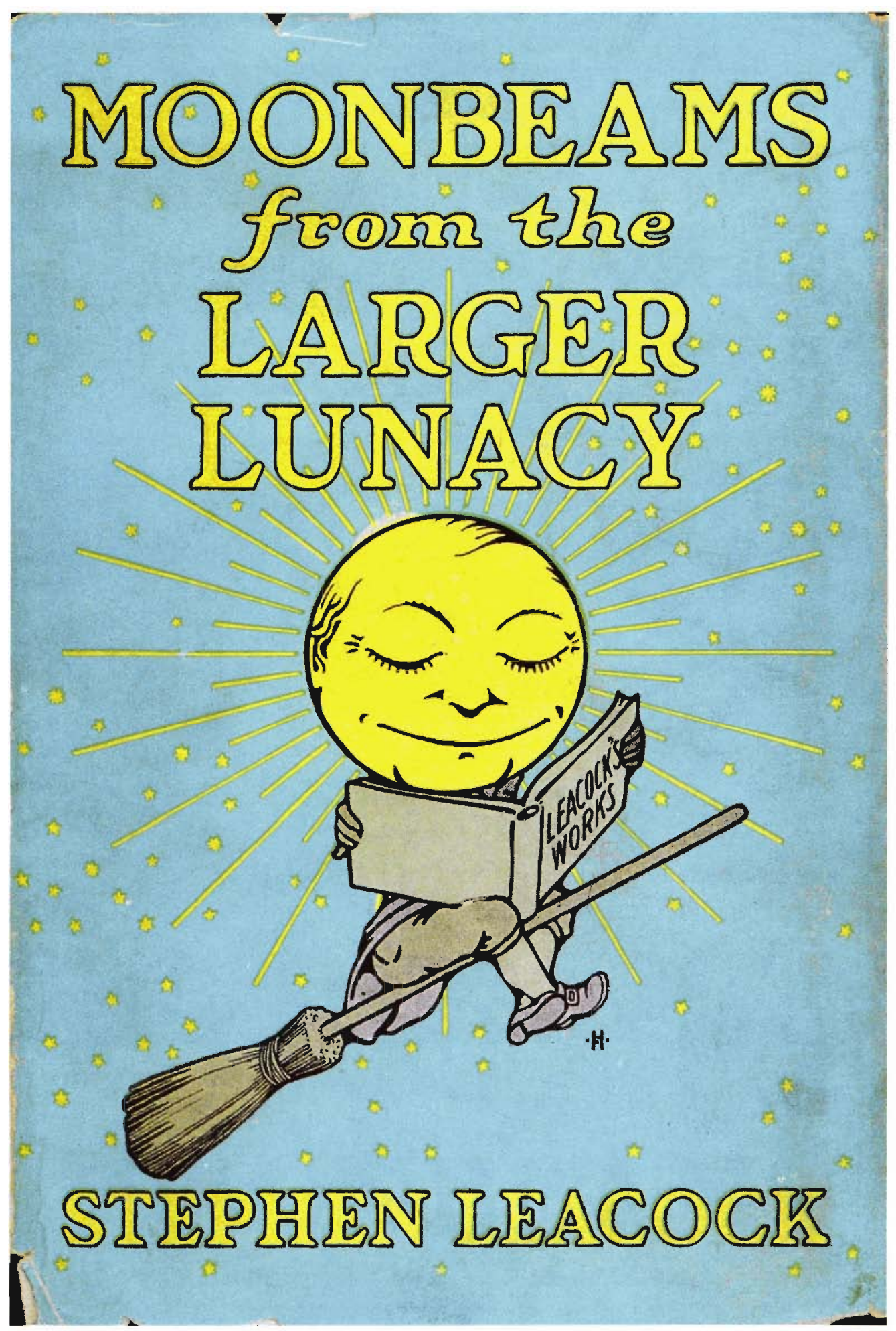

London: John Lane, The Bodley Head Third Edition [1919] 
Stephen Leacock and His Books

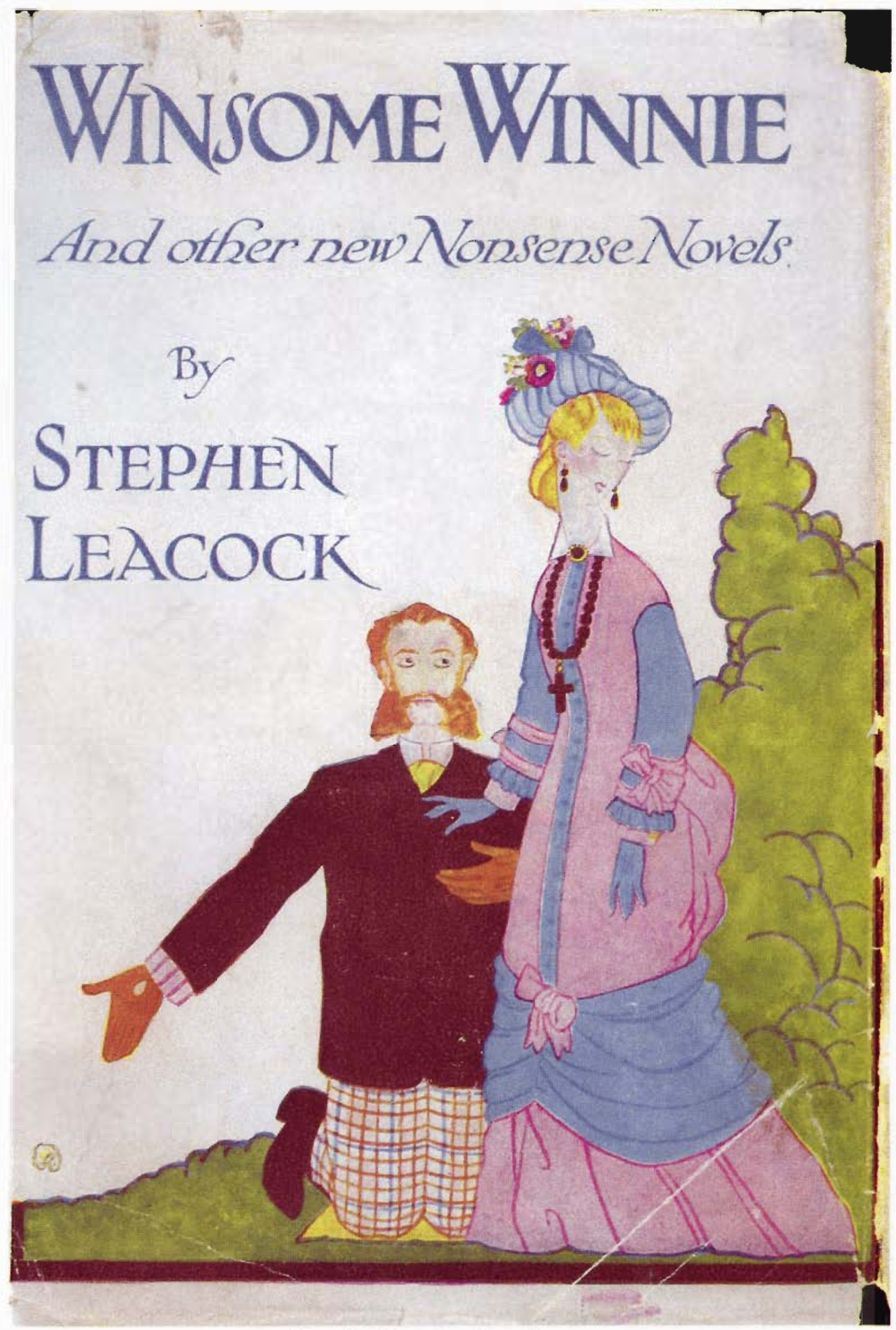

New York: John Lane Company

1920 
Stephen Leacock and His Books

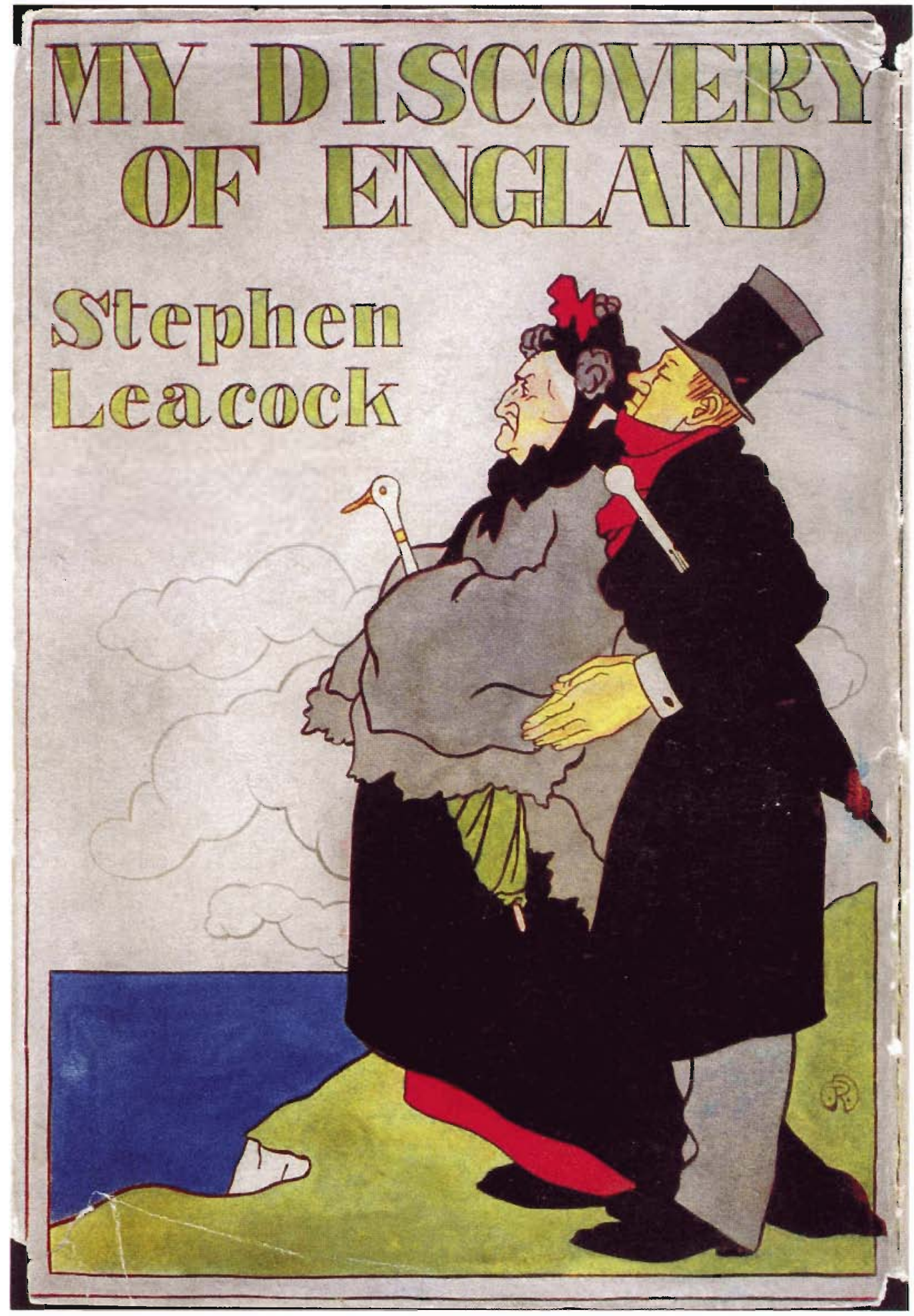

London: John Lane, The Bodley Head

1922 
Stephen Leacock and His Books

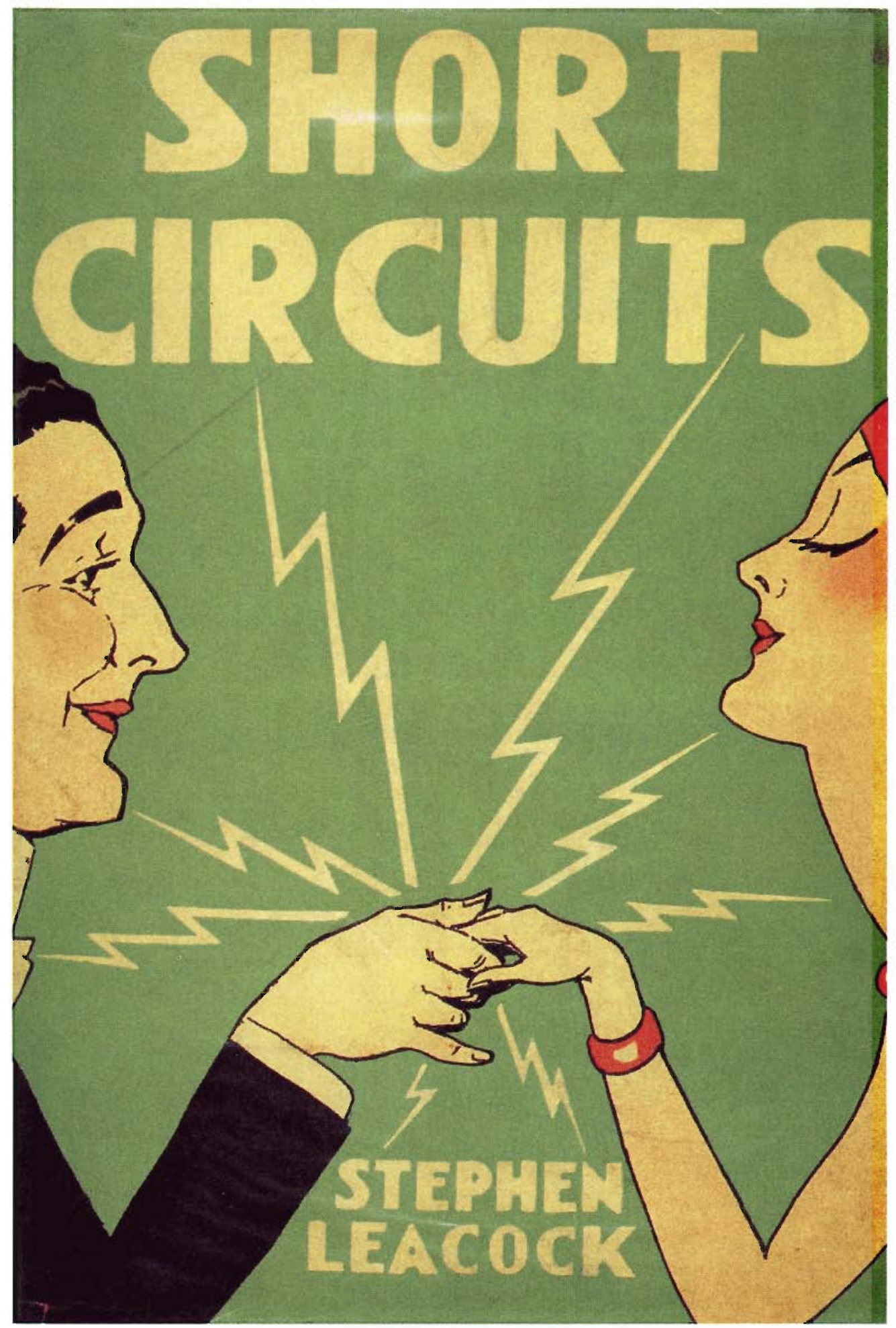

New York: Dodd Mead and Company 1928 


\section{* REPERTORY PLAYS N• 124 BEHIND THE BEYOND}

$\stackrel{n}{+}$

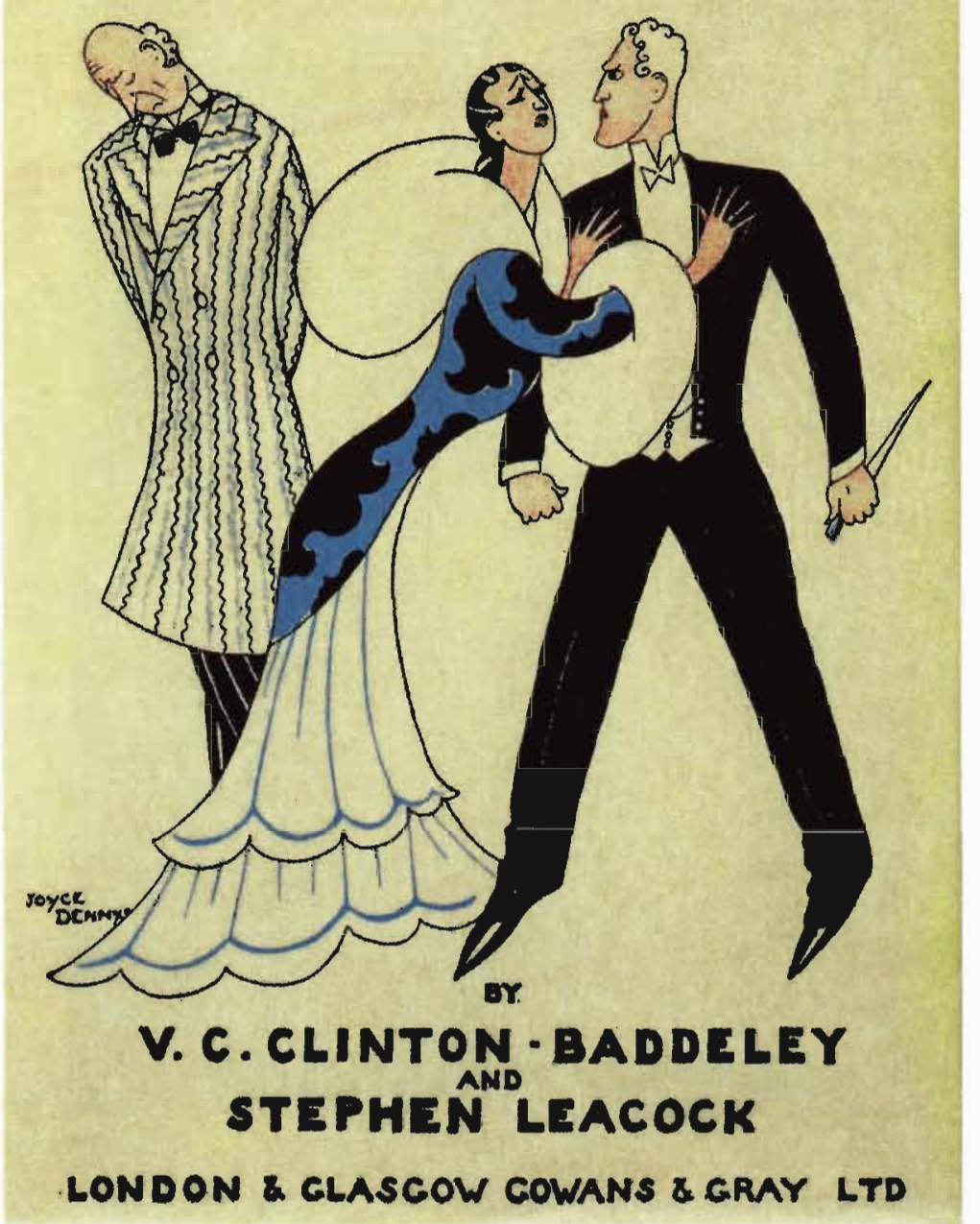

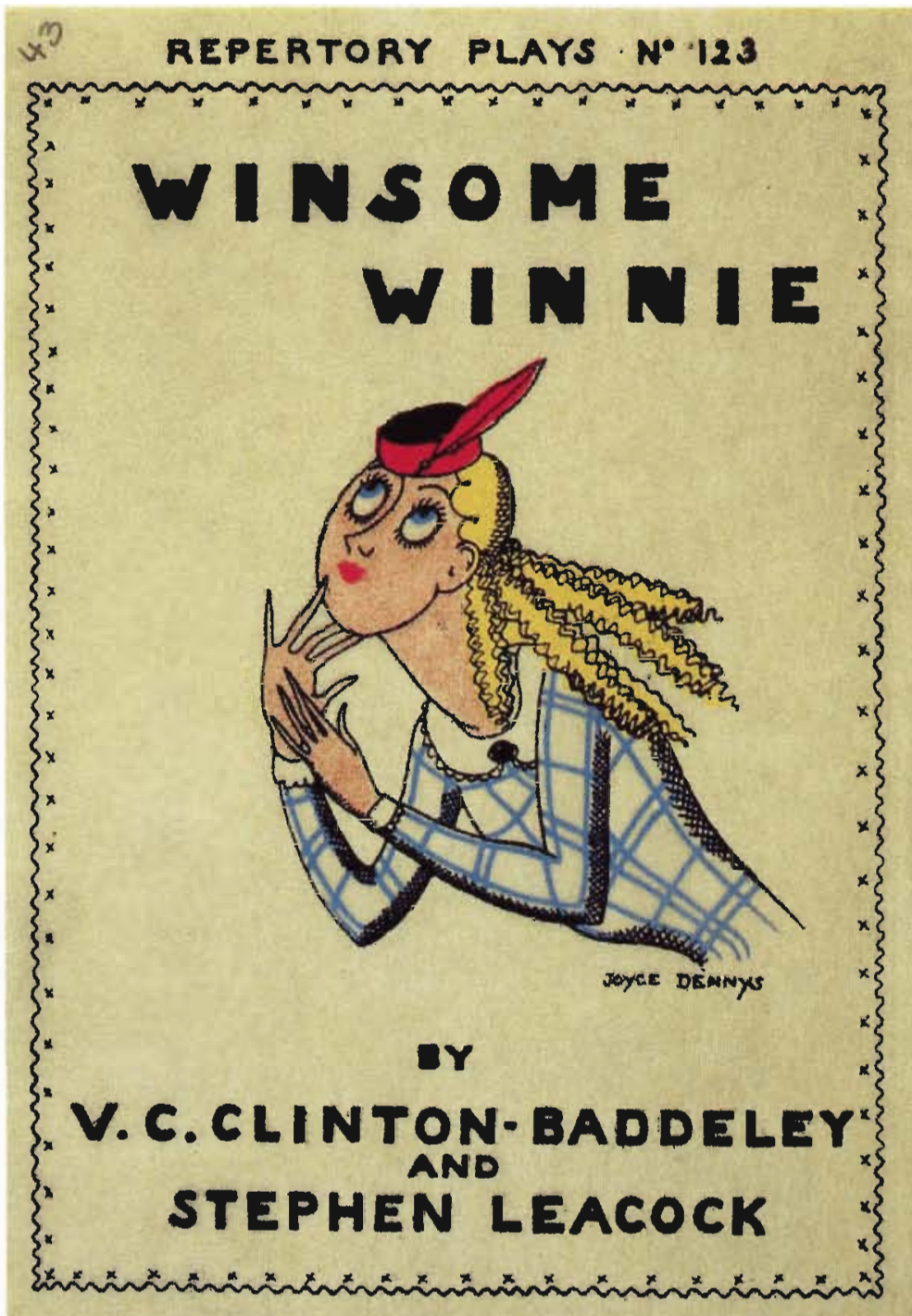

LONDON \& CLASCOW: GOWANS I CRAY LTO 

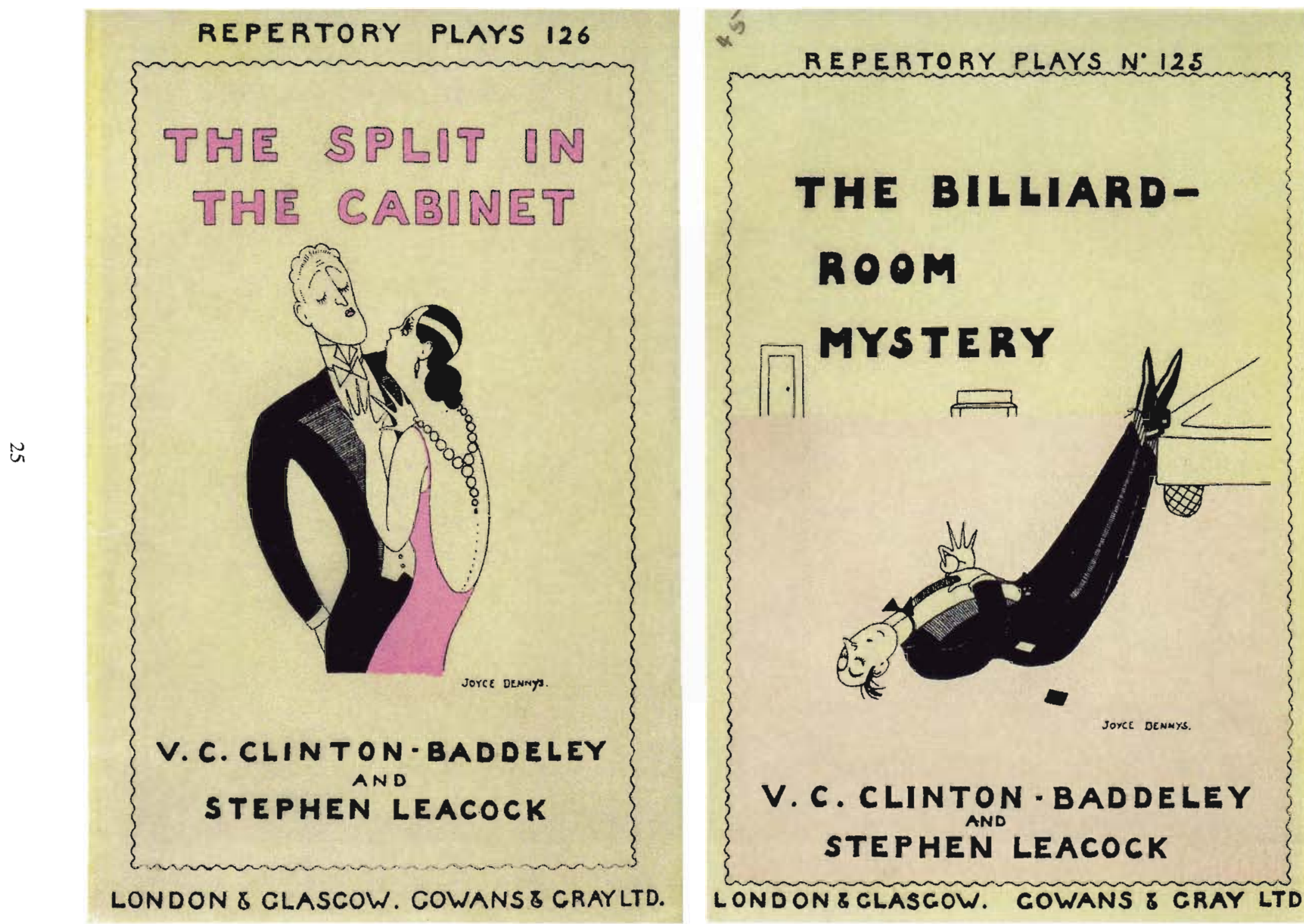
Stephen Leacock and His Books

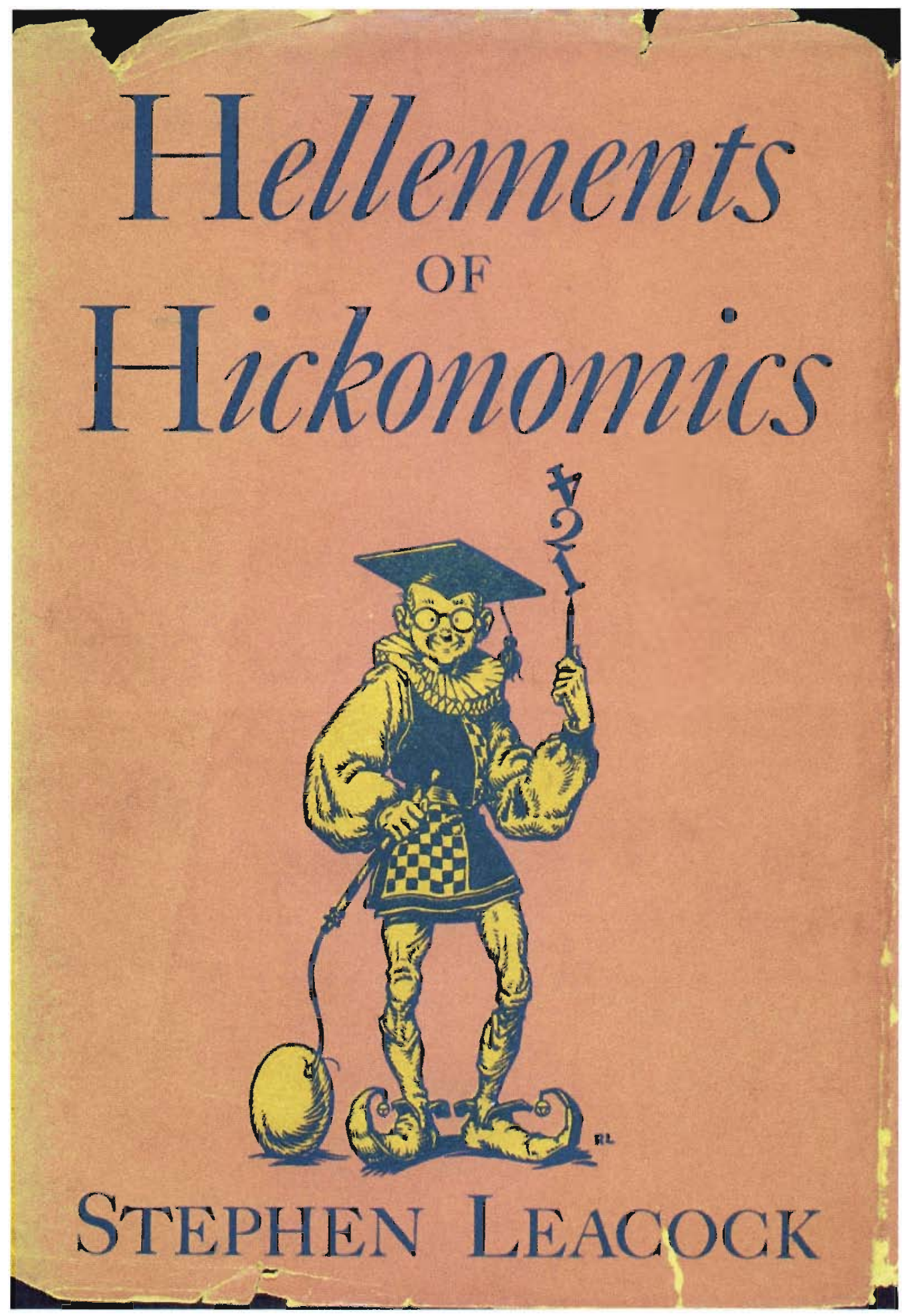

New York: Dodd, Mead \& Company 1936 


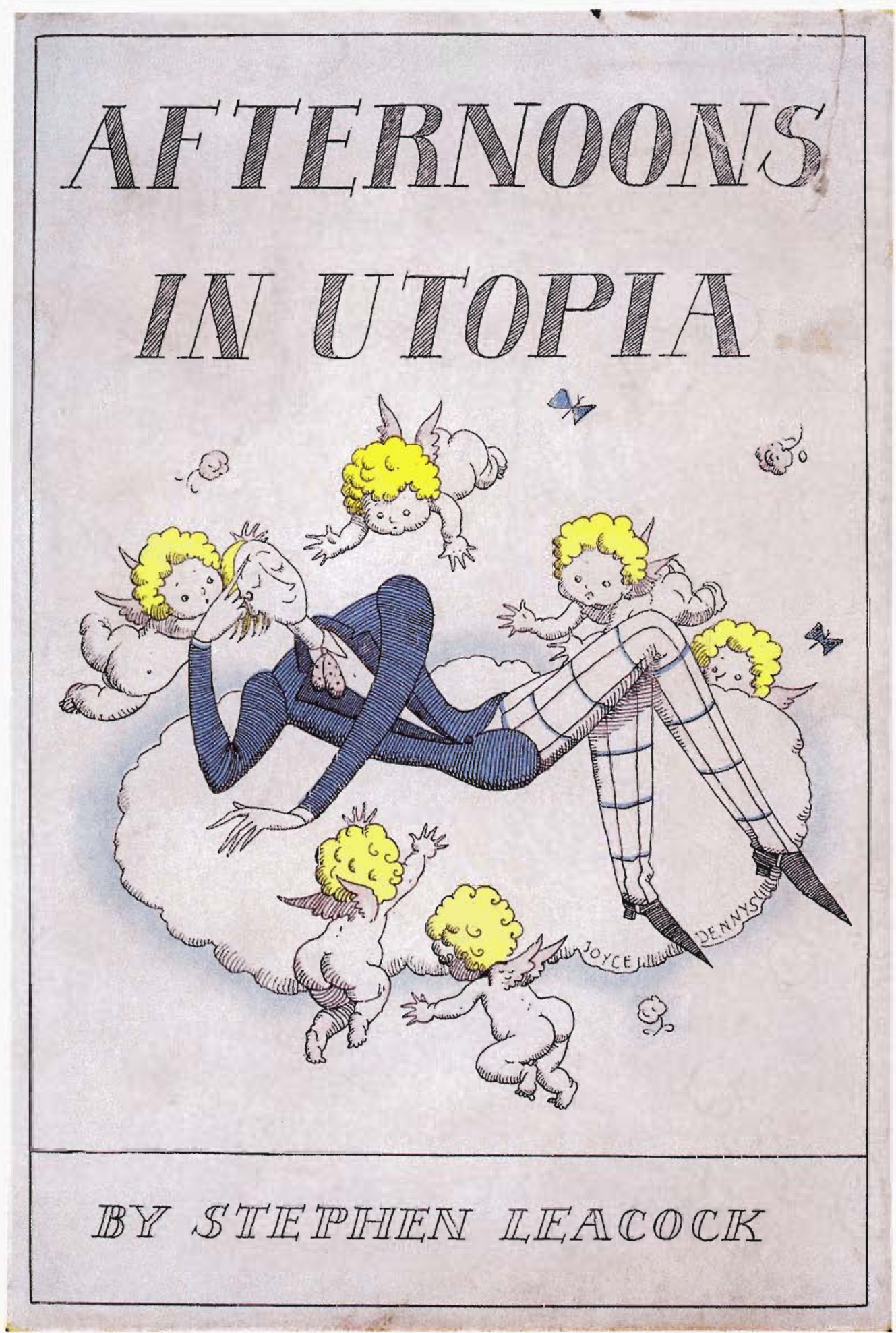

Toronto: The Macmillan Company of Canada Ltd. At St. Martin's House 1932 
Stephen Leacock and His Books

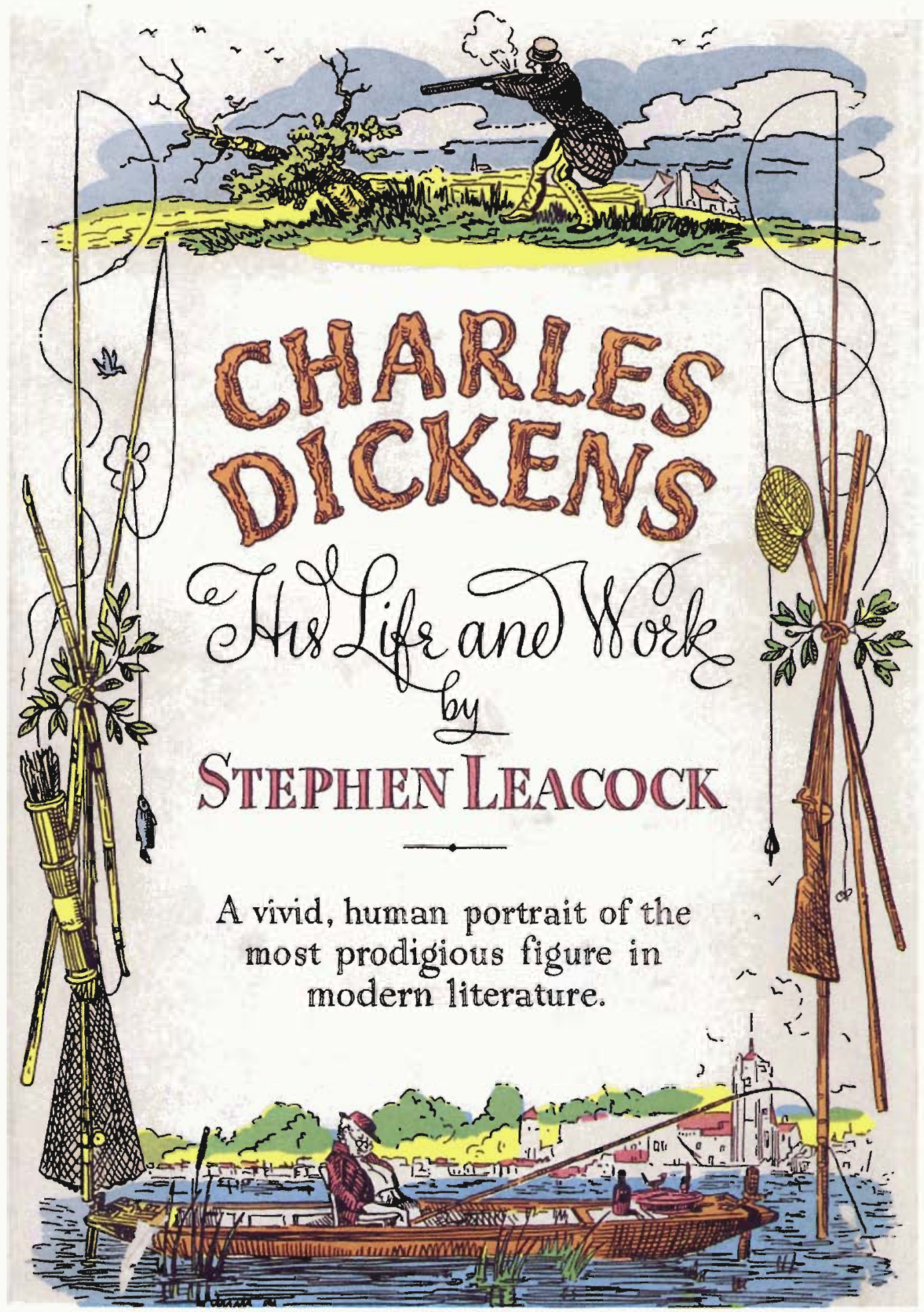

Garden City, New York: Doubleday, Doran and Company, Inc. 1934 
Stephen Leacock and His Books

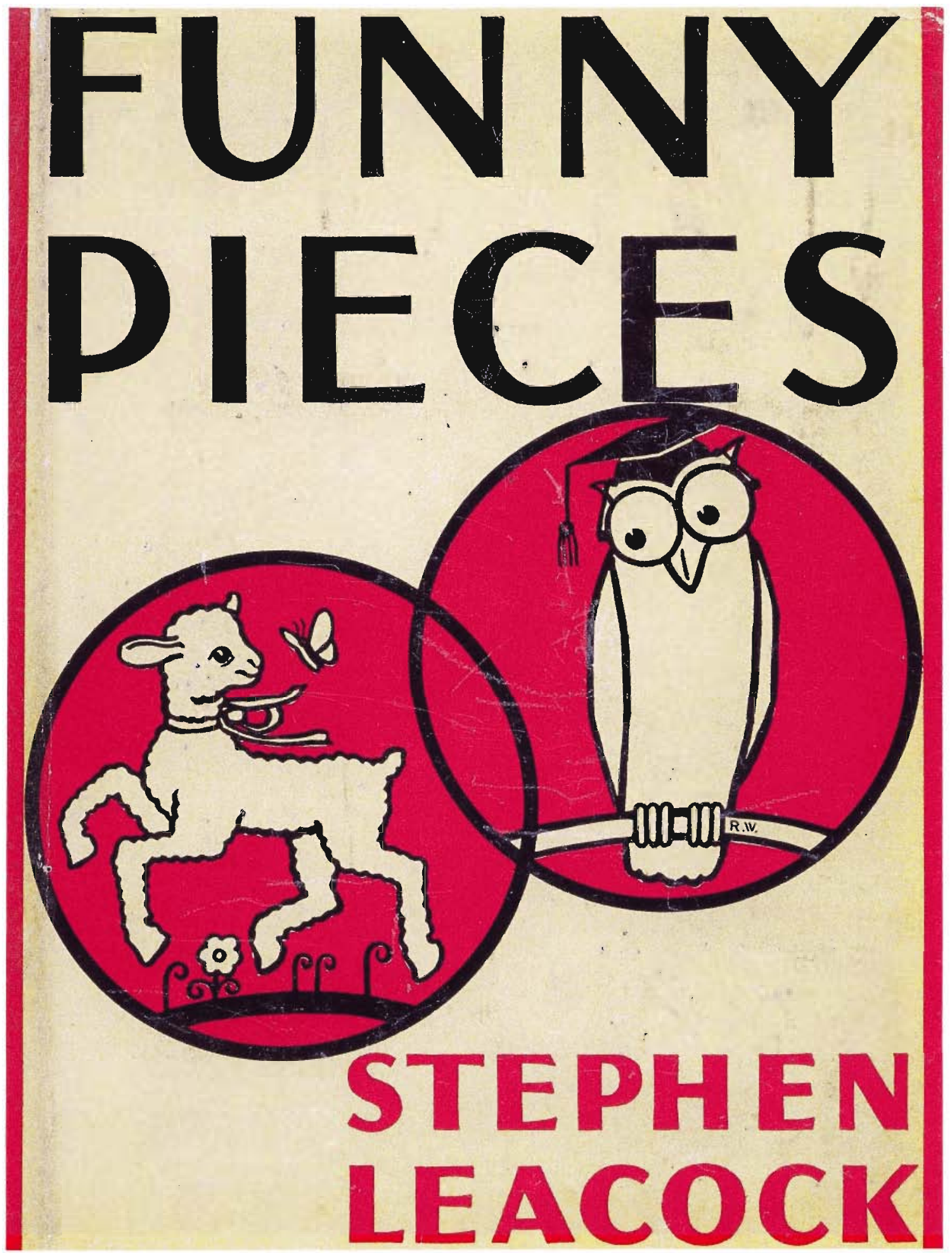

New York: Dodd, Mead \& Company 1936 
Stephen Leacock and His Books

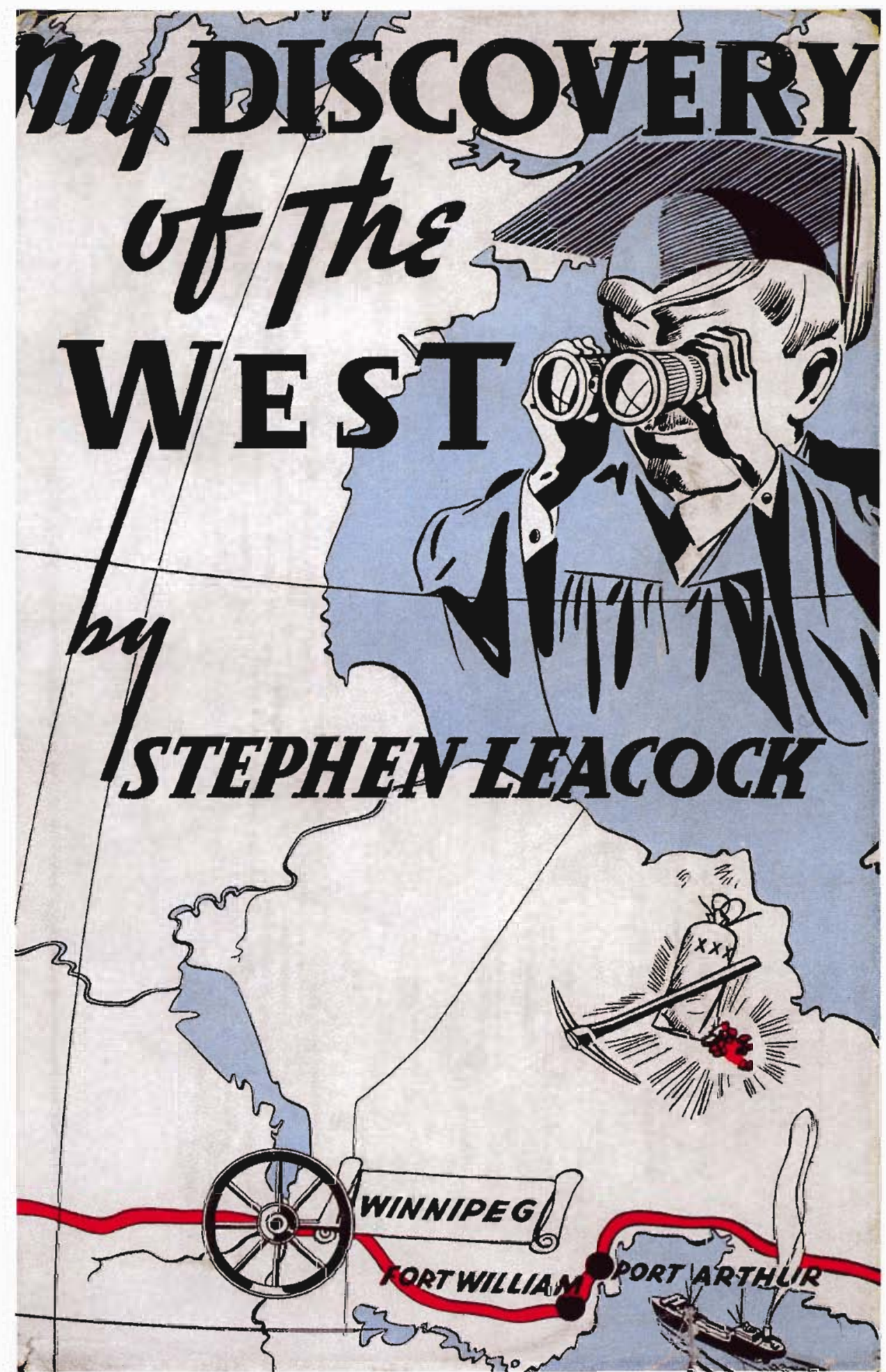

Toronto: Thomas Allen, Publisher 1937 
Stephen Leacock and His Books

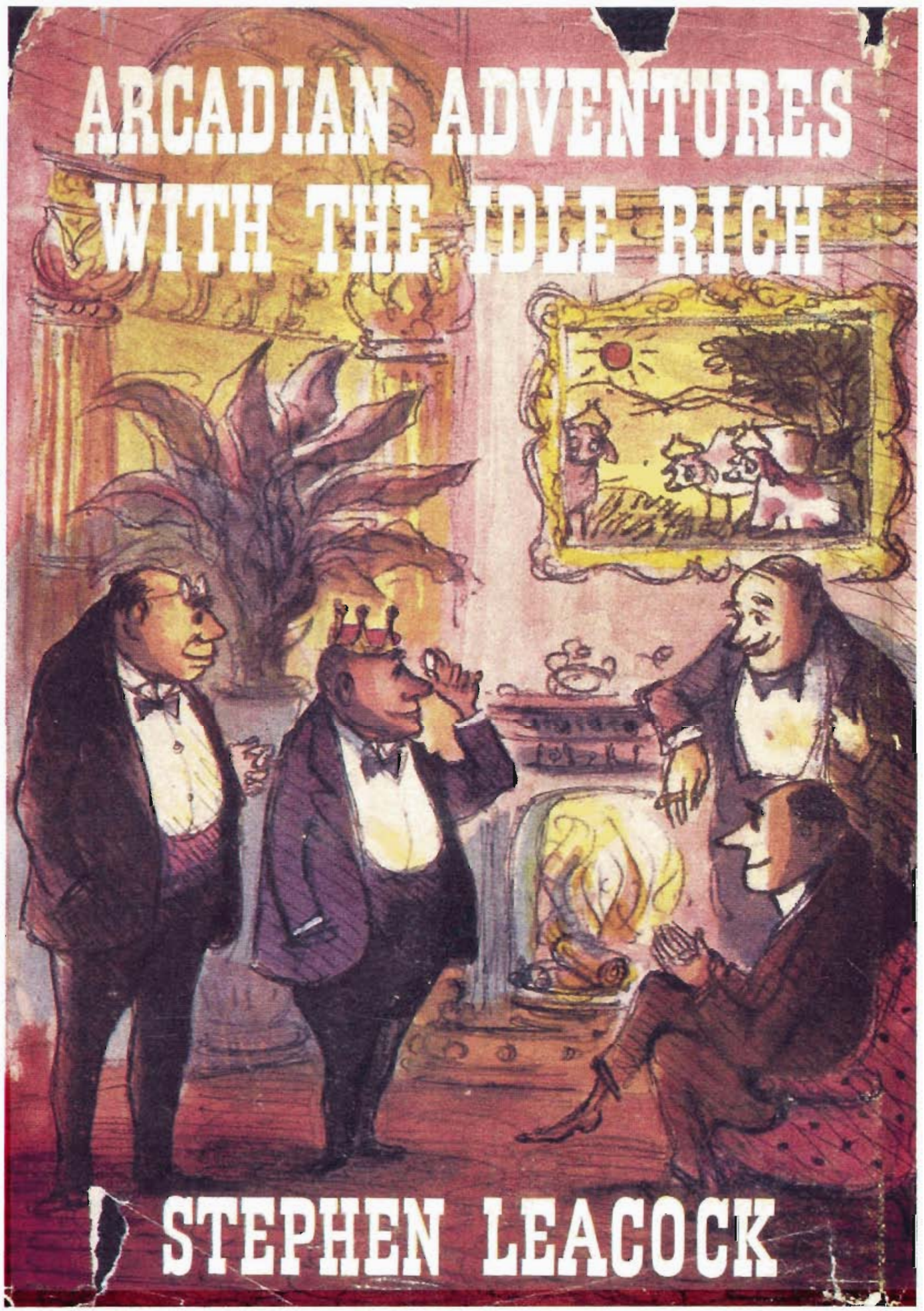

London: John Lane, The Bodley Head

Cheap Edition, 1930, Reprinted 1952 

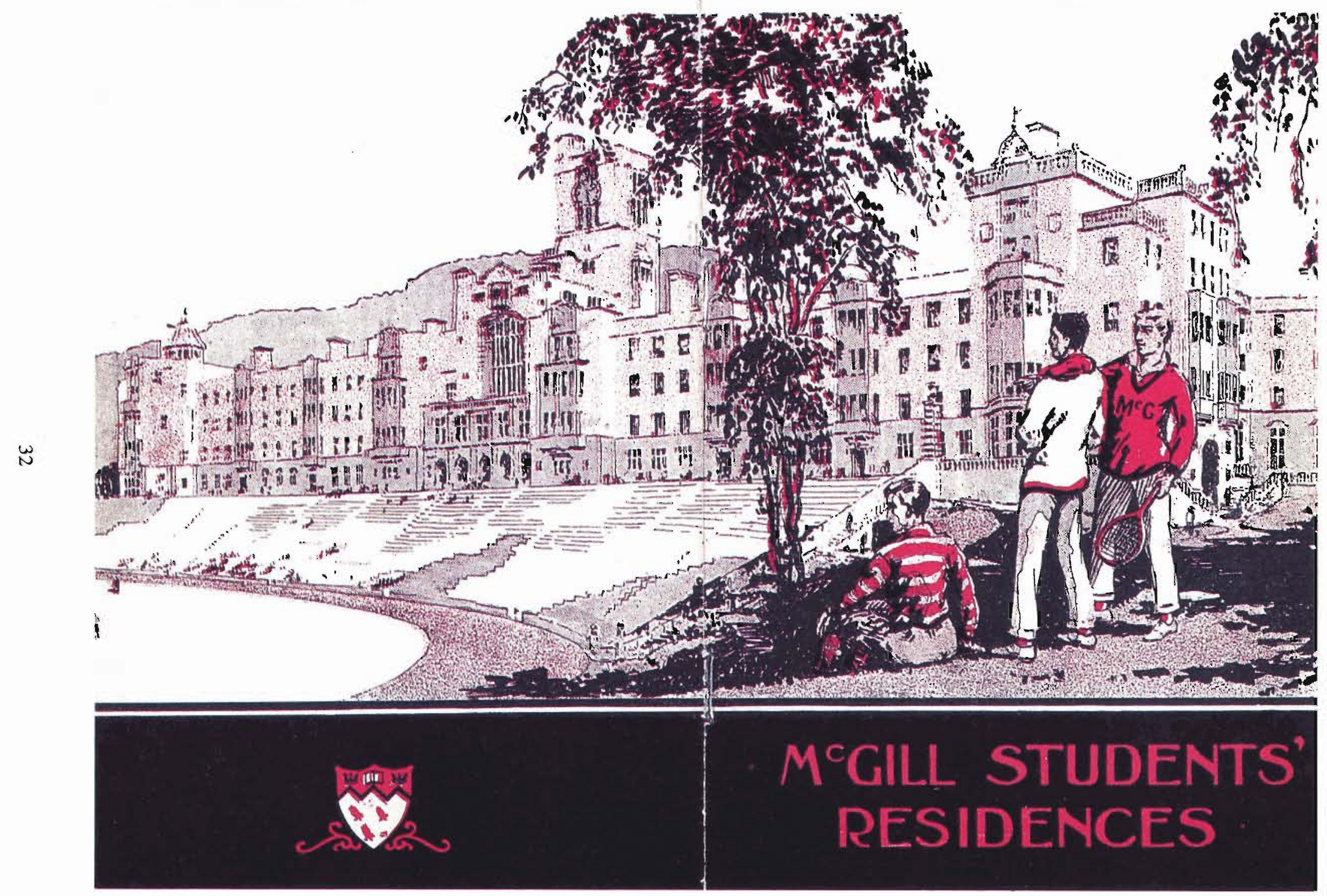

The Need for Dormitories at McGill Montreal, McGill Centennial Endowment 